\title{
The Early Stages of Spindle-Formation in the Pollen-Mother-Cells of Larix.
}

\author{
BY
}

\author{
CHARLES E. ALLEN, \\ Instructor in Botany in the University of Wisconsin. \\ With Plates XIV and XV.
}

INTRODUCTION.

UCLEAR division in the pollen-mother-cell of Larix 1 davurica, Trautv., was described and figured by Belajeff ('94). He finds, in the early prophases of the first mitosis, a system of radial fibres extending from the nuclear membrane to the cell periphery. Later, a close felt-like layer of fibres, or meshes, appears just without the nucleus; some fibres are still left in the peripheral cytoplasm. This arrangement, he suggests, may have rẻsulted from a drawing together of the radial fibres about the nucleus; but he finds none of the intervening stages. The fibrous material already present within the nucleus increases in amount, forming a dense network; the nuclear membrane disappears, and with it the distinction between intra- and extra-nuclear fibres. The peripheral fibres group themselves so as to converge toward points (one to four in a section) near the cell-wall, and the fibres of the central mass become so arranged with reference to these points as to form a multipolar spindle. Bundles of fibres connect the chromosomes, lying in the central region of

[Annals of Botany, Vol. XVII. No. LXVI. Márch, 1903.] 
the spindle, with the poles. The number of poles is reduced to two, possibly by fusion, resulting in a typical bipolar spindle. Belajeff's observations of Lilium and Fritillaria pollen-mother-cells agree, so far as they go, with those of Larix. A dense intra-nuclear network is formed; then knots, possibly, he thinks, centrospheres, appear at various places in the cytoplasm, from which fibre-bundles penetrate the nuclear membrane and attach themselves to the chromosomes. The membrane disappears and a multipolar figure is formed, which passes into a bipolar spindle.

Strasburger's ('95) description of some stages of the same division in the pollen-mother-cell of Larix europaea corroborates that of Belajeff as to the felted stage, the disappearance of the nuclear membrane, the formation of a central fibrous system, a multipolar and finally a bipolar spindle. Němec ('98 b) describes quite differently spindle-formation in $L$. decidua (L. europaea, DC.). He finds an early stage of cytoplasmic radiation, succeeded by an aggregation, just without the nucleus, of granular material, sharply separated from the much-vacuolated outer cytoplasm. Next to the membrane appears a hyaline region, which grows at the expense of the granular zone. In the hyaline layer appears a reticulum; this develops into a system of fibres, which orient themselves into a multipolar figure. Fibres also appear within the nucleus, the membrane disappears, and from the whole fibre-complex a bipolar spindle is developed.

Belajeff was the first to interpret a multipolar as a stage in the development of a bipolar spindle ; but Strasburger ('80) had, some years earlier, figured a tripolar spindle in the endosperm of Reseda, and had described similar figures in Ornithogalum and Leucojum. Later, he ('88) figured the spindle in Leucojum; also a multipolar spindle in the equatorial plate stage from the endosperm of Allium, whose great number of chromosomes led him to explain it as due to a fusion of several nuclei. A felted stage, similar to that described by Belajeff, had been found by Strasburger ('88) in Leucojum. 
In recent years, a multipolar origin of the spindle has been found in many Spermatophytes. Such a stage is described in the pollen-mother-cell of Lilium by Farmer ('93, '95 d), by Strasburger ('95), Miss Sargant ('97), and Mottier ('97). Farmer's preliminary note ('93), indeed, preceded the publication of Belajeff's paper, just cited, but the substance of the latter's discoveries had been stated in two earlier Russian notes. Mottier finds, succeeding a radial stage, a felted layer just without the nucleus, from which fibres extend toward the cell-wall so as to form a number of poles. But as the nuclear membrane disappears and the fibres penetrate the nuclear cavity, the multipolar condition often disappears, to recur when the cavity is completely filled by the fibrous mass. In the pollen-mother-cells of Podophyllum and Helleborus the process is similar, except that there is no multipolar arrangement until after the membrane disappears. A multipolar stage occurs, too, according to Mottier, in the second mitosis in the pollen-mother-cell of Lilium; also ('98) in the divisions in the embryo-sac of Lilium and Helleborus. Multipolar figures which develop into bipolar spindles are described in the pollen-mother-cells of Hemerocallis, by Juel ('97); in those of Nymphaea, Nuphar, Limodorum and Magnolia, by Guignard ('97 $a$, '97b, '98); of Cobaea and Gladiolus, by Lawson ('98, '00); of Bignonia, Symplocarpus and Peltandra, by Duggar ('99, '00); of Convallaria and Potamogeton, by Wiegand ('99) ; of Arisaema, by Atkinson ('99); of Passiflora, by Miss Williams ('99); of Lavatera, by Miss Byxbee ('00); of Magnolia and Liriodendron, by Andrews ('01); and in those of Galtonia and Convallaria, by Schniewind-Thies ('01). Schniewind-Thies finds similar figures in the embryo-sacs of Galtonia, Convallaria, Scilla and Tulipa; and Duggar ('99) describes them in the embryo-sac of Bignonia. Of the cases above mentioned, a felted stage preceding the multipolar is described in Hemerocallis, Nymphaea, Nuphar, Limodorum, Magnolia (Guignard and Andrews), Gladiolus, Peltandra, Convallaria (Wiegand), Potamogeton, Lavatera and Liriodendron; and an earlier radial stage is found in Cobaea, Peltandra, 
Passiflora and Lavatera, and in the second division in Magnolia and Liriodendron (Andrews).

In a type of spindle-formation first described by Rosen ('95) in the root-tip of Hyacinthus, a thin hyaline extranuclear zone is seen, whose material becomes aggregated on two opposite sides of the nucleus. Within each cap so formed, fibres appear and grow in length, attaching themselves at one end to the nuclear membrane and finally converging at the other end to a common point. Then the membrane disappears and the spindle is completed. Nevmec ('97,'98 $a$, '98 $b$,'99 $a$, '99 $b$,'99 ) describes spindle-formation from similar extra-nuclear caps in root-tips and other vegetative tissues of Allium, Hemerocallis, Solanum, and a long list of plants. He finds that in general the spindles in vegetative cells are from the start bipolar, while those in reproductive cells are originally multipolar. Hof ('98) finds similar polar caps in the root-tips of Ephedra and Vicia. In the former case, the spindle is originally bipolar, in the latter monaxially multipolar, becoming bipolar. Schaffner ('98, '01) describes spindles arising from similar extra-nuclear caps in the roottips of Allium and Erythronium; and Fullmer ('98, '99) finds the same thing in pine seedlings, and also in pollen-mothercells of Hemerocallis, where, however, he describes also an early radial stage. Miss McComb ('00) relates a similar history in the root-tips of Allium, Vicia and Erythronium, except that instead of the early hyaline layer she finds a kinoplasmic weft or felt surrounding the nucleus; and it is this felt that becomes aggregated into the polar caps.

Strasburger ('00, p. I I 8 ) has pointed out that in the vegetative divisions described by Němec the spindle primordium ('Anlage') at each end of the nucleus is at first composed of separate spindle-bundles, not converging to a common point. He proposes for this condition the term 'multipolar diarch,' as distinguished from the 'multipolar polyarch' form common to reproductive cells, in which poles arise on all sides of the nucleus. He finds, in the root-tips of Ephedra and Vicia, a finely fibrous extra-nuclear layer which becomes aggregated 
into polar caps, and from these caps fibres grow out into a liquid which appears between the fibrous cap and the nuclear membrane. But there is no sharp line of distinction between the two methods of spindle-formation; for in the pollen-mother-cell of Iris the origin of the first spindle is multipolar polyarch, that of the second multipolar diarch; while in the pollen-mother-cell of Nymphaea the origin of the first spindle is similar to that of the second in Iris. Duggar ('00) finds, too, that in the division of the microspore nucleus of Symplocarpus and Peltandra the spindle is originally multipolar diarch, the fibres being arranged perpendicularly to the wall near which the nucleus lies. Mottier ('98) describes, in the vegetative cells of Lilium, a multipolar stage preceded by an extra-nuclear felt, just as in pollen-mother-cells; and a multipolar spindle is figured by Ikeno ('98) in the embryo of Cycas.

Multipolar spindle-figures have an important bearing on the question as to the presence or absence of central bodies (attraction-spheres, centrospheres, centrosomes, \&c.). We have seen that the evidence is conclusive for the general existence of a multipolar stage in the history of the spindle in the cells of the flowering plants; and such a stage seems to negative the possibility of the formation of the spindle in these plants through the agency of centrosomes which station themselves at opposite points in the cell, so initiating mitosis and determining the position of the spindle-poles. But Guignard, who ('91 $a$, '91 $b$, '91 $c$ ) first described attractionspheres in Phanerogams, has more recently ('97 $a$, '97 $b,{ }^{\prime} 98$ ) maintained that the poles of the multipolar figure are often occupied by centrosome-like granules, which are, he holds, true kinetic centres, and that the bipolar stage results from their fusion into two typical centrospheres. A very similar process has been described by Moore ('94) in certain animal cells. But even Guignard admits that the spheres may disappear in the resting stage and be formed de novo during mitosis, sometimes not until after the appearance of the multipolar spindle; in the latter case, the cones arise by the 


\section{Allen.-The Early Stages of Spindle-Formation}

activity of the kinoplasm in the absence of undifferentiated dynamic centres. In spite of numerous accounts of central bodies, the great weight of evidence now seems to be against their existence in the Seed Plants, if we except the still disputed case of the 'blepharoplast.' A full résumé of the centrosome discussion has lately been published by Strasburger ('00), who has still more recently ('01) applied to the pollenmother-cells of Asclepias and Cynanchum, with negative results, all the methods used for the demonstration of the central bodies in animal tissues. The observations and experiments of Hottes (reported by Strasburger, '00) and of Němec ('99 $d$, '01) indicate that kinoplasmic or nucleolar granules or masses may often appear at or near the spindlepoles, and that their occurrence is favoured by certain stimuli, as, for instance, subjection to low temperatures. Demoor ('95) also finds that 'centrosomes' are made visible by cooling.

The only history of a multipolar spindle so far completely worked out among the Pteridophytes is that of the sporemother-cell of Equisetum, described by Osterhout ('97). He finds, just without the nucleus, a blue-staining cytoplasmic layer, which becomes fibrous; the fibres are at first parallel to the nuclear membrane, but later take on a radial arrangement, many of them extending to the plasma-membrane; then they group themselves into a multipolar figure. The nuclear membrane disappears, and the extra- and intranuclear fibres form a continuous system, whose poles fuse in two groups, forming a sharply bipolar spindle. No centrosomes are present at any stage. The multipolar origin of this spindle is corroborated by Němec (' $98 a$ ); but Campbell ('95, p. 427) finds directive spheres present in the divisions of the spore-mother-cell, and describes no multipolar stage. Smith ('00 a) notes that the spindle in the microspore-mothercell of Isoëtes appears to have a polycentric origin. In the spore-mother-cells of Osmunda, he ('00 b) describes the formation of a spindle from two extra-nuclear polar caps-a 'multipolar diarch' origin. Occasional tripolar figures he 
considers abnormal. Spindle-formation from polar caps is found in the meristem of Psilotum by Rosen ('95), in vegetative tissues of Equisetum, Aspidium and Alsophila by Němec ('98 a, '98 b,'99 a), and in vegetative cells of Aspidium by Hof ('98). Central bodies have been described in the Pteridophytes by numerous observers; but the evidence for and against their existence here is practically the same as in the case of the Seed Plants, and here as in the higher group the preponderance seems to be on the negative side of the argument.

A peculiar form of quadripolar spindle, suggestive of the multipolar figures already described, is found by Farmer ('94, '95 $a, ' 95 b, 95 c$ ), in certain Hepaticae whose spores are formed by the division of the mother-cell into four lobes. In Pallavicinia he finds that four daughter-nuclei are formed simultaneously, one at each of the poles; but in other cases the original poles approximate in pairs to form either a sharply bipolar spindle or one with forked ends, and the division results in two daughter-nuclei, each of which again divides. Davis ('01) finds a quadripolar figure in Pellia, but he interprets it as a stage in spindle development in which a fibrous extranuclear weft takes this peculiar shape in consequence of the lobing of the cell. He ('99) also finds a felted stage in the developing spindle in the spore-mother-cell of Anthoceros, followed apparently by a multipolar, then by a bipolar stage. Centrospheres and centrosomes have been described in a number of liverworts.

The only case of spindle-formation reported among the Thallophytes which seems to conform to the multipolar type is in the vegetative cells of Chara, described by Debski ('98). The bipolar spindle develops, through stages which he did not follow, from a central fibrous system; the latter is partly of nuclear and partly of cytoplasmic origin. This isolated case emphasizes the width of the gulf that seems to separate the Characeae from other Thallophytes. Central bodies which take part in spindle-formation, which divide, and, in some cases at least, persist through the resting stage, have 
been found in species representing diverse groups, and it is generally recognized that a method of spindle-formation accompanied by the activity of a centrosome is at least of widespread occurrence among the lower plants.

As we have seen, there is much uncertainty and variance in the accounts of different authors as to what takes place in the early history of the spindle in the higher plants, previous to the appearance of the extra-nuclear felt. Besides, the presence of centrosomes, though rendered extremely improbable, is not admitted by all writers, at least, to be entirely excluded by known facts as to the multipolar origin of the spindles. For these reasons, special attention has been paid in the present investigation to the early prophases of mitosis, and an attempt has been made to follow closely the history of the cytoplasmic structures in these stages. The problem here involved is a purely physiological one, and the description of structures occurring in isolated stages of karyokinesis is by no means sufficient for its solution. A complete series of stages, showing the changes actually going on within the cell, must be studied, and their connexion shown. From this point of view, much of the discussion regarding the presence or absence of 'centrosome-like granules' at the spindle-poles is seen to be useless. There can be no doubt, from the citations already given, that granules or larger masses are often to be found at the poles; but nothing can be determined as to the significance of these bodies until the complete history of the spindle has been traced.

\section{ORIGINAL OBSERVATIONS.}

The following description applies to the first nuclear division in the pollen-mother-cells of Larix europaea, DC. Male cones were fixed at various times during the fall, winter and spring, both from material just taken from the trees and from that whose development was hastened by keeping it for from one to four days in a warm room. Strasburger ('00, p. 68) finds that material forced in this way yields the same karyokinetic figures as that which has developed more slowly 
out-of-doors. Of several fixations tried, the best results were obtained with Flemming's stronger solution. The sections, five microns in thickness, were stained with the triple stain. I have also had the privilege of examining some similarly fixed and stained preparations made by Professor R. A. Harper and by Mr. H. G. Timberlake. Several of my drawings are from Professor Harper's preparations, and one is from one of Mr. Timberlake's. Living pollen-mother-cells have also been examined and compared with killed material.

The process of spindle-formation may be considered as divided into five periods or stages; the division is somewhat arbitrary, and consecutive stages are in no case sharply separated from one another.

\section{The Pre-Radial Stages.}

The earliest material that I have studied was gathered and fixed October 24. The pollen-mother-cells are still packed closely together, but are beginning to round up and separate from each other. Each cell seems to be bounded only by a distinct blue-staining plasma-membrane; at least, I have been unable to distinguish, by the use of the orange stain, any layer of cell-wall material. Between the separating cells is a blue-staining material, possibly the old disorganizing cellwall, sometimes appearing as a distinct layer of some thickness, sometimes as a cloudy mass. Fig. I, Pl. XIV, shows a pollenmother-cell in this stage. Groups of red-staining bodies, the chromatin tetrads, are seen in the nucleus, just within, or often in contact with, the nuclear membrane; segmentation of the spirem thread, therefore, has already occurred. There is usually a single nucleole (sometimes two), , in general of a rounded and somewhat irregular shape. Much of the irregularity of outline, however, is due to adhering clumps of a usually less dense and blue-staining substance-the linin. Linin is also found in contact with the chromosomes, and, in the form of ragged, wavy, granular fibres, connecting the chromatin groups with each other, with the nucleole, or running from nucleole or chromosomes to the nuclear membrane. 
Often the nucleole becomes by this means the centre of a system of radiating fibres, as is shown at a later stage in Fig. 2. The only visible structure in the cytoplasm in the earliest stage is a fibrous network. The apparently empty meshes are of varying shapes and sizes; in general they are smallest near the nucleus and increase in size toward the periphery of the cell. Scattered about upon the fibres and between them are granules, staining blue like the fibres. These granules are probably, in large part at least, cross-sections of fibres, and they are no more numerous than such sections would be likely to be in such a network. Often they are shown by focusing to extend through the thickness of the section.

Fig. 2 is from material gathered and fixed March I 5 ; the fixation is according to Vom Rath's picric-acetic-osmic acid and platinum chloride formula. There has evidently been no great change during the winter. The Vom Rath fixation, however, does not permit of so good a differential stain as the Flemming, and the preparations are in general not as satisfactory. The fibrous network is still present, though not well brought out ; between the meshes, especially near the nucleus, is a granular or cloudy substance, but the large peripheral meshes are still empty, giving the outer part of the cell a vacuolated appearance. In the cytoplasm are seen occasional small rounded bodies of distinct outline, staining homogeneously and a little more deeply than the rest of the cytoplasm.

Fig. 3 shows a somewhat later condition (in Flemming fixation, as are all the remaining figures). The cells have now rounded up and are provided with a relatively thick cell-wall. The blue intercellular substance has disappeared, and the cells float in a colourless liquid. The cytoplasm now plainly contains two constituents, the fibrous meshwork first observed, which stains blue, and a cloudy or very finely granular, orange-staining material. The latter substance does not occupy all of the inter-fibrous spaces, but clear areas of varying size are also scattered through the cytoplasm. Some- 
times the clear spaces are larger and more numerous in the peripheral region, but often, as in the cell shown in Fig. 3, the cytoplasm presents in this respect a very uniform appearance. The granules, or sections of fibres, are present as before, and also the larger rounded cytoplasmic bodies, which stain less densely blue than the fibres. Often a cytoplasmic fibre can be clearly traced as it passes through the nuclear membrane and is attached to one of the chromatin groups. For this purpose sections are specially favourable which cut the nucleus tangentially; in such a section a fibre running diagonally to the cutting-plane can be followed, by a change of focus, through the membrane, which is transparent and is here visible only as a bluish cloud. A portion of such a section is shown in Fig. 4 .

Comparison of living cells at this period is helpful. The outlines of the large round or elliptical nucleus, one or two nucleoles, usually near the centre of the nucleus, and the chromosomes just within the nuclear boundary, are all plainly visible; and some of the longer linin fibres can be made out. Little can be determined in living material regarding cytoplasmic structures; occasionally one of the coarser fibres can be traced for some distance.

\section{The Radial Stages.}

Very soon the cytoplasmic fibres begin to show a definite arrangement. In a section through a single cone may often be found a series of stages from the one just described to a distinctly radial arrangement (Fig. 5). The fibres arrange themselves so that many of them extend perpendicularly from the nuclear membrane out into the cytoplasm or even to the periphery of the cell. At first, however, most of the radial fibres are relatively short and end in the cytoplasm. They are also in general not straight, but rather irregularly wavy. A vacuolated region may still be present in the peripheral cytoplasm, as appears in Fig. 5 .

The fibres soon increase in length, and a complete system of fairly straight radial fibres is formed, extending from the 


\section{Allen.-The Early Stages of Spindle-Formation}

nuclear membrane to the plasma-membrane. In the cell represented by Fig. 6 , there is a very slight plasmolysis around much of the cell periphery; the plasma-membrane, stained deep blue like the fibres, is separated from the orange cell-wall, and it is plain that the fibres terminate in this membrane. The cytoplasm has also shrunken away slightly from one side of the nuclear membrane, and one fibre can be traced across the gap to the membrane and into apparent continuity with an intra-nuclear fibre. The number of blue cytoplasmic granules shown in median section is now much less than in the earlier stages, as would be expected if they are sections of fibres. Often the fibres are connected with each other by branches; this may be taken to indicate that the radial figure has resulted from a pulling out and rearrangement of the meshes of the earlier network. A study of the succession of stages tends to strengthen this view of the origin of the radial fibres. However, it seems plain that there is also an actual growth in length of the fibres after they have assumed the radial position. The possibility of a combination of the two processes-a pulling out of the meshes and a growth of the fibres - will be discussed later.

\section{The Formation of the Felt.}

A folding-over of the fibres (Figs. 7-II) now occurs, so that they come to assume a position parallel to the nuclear membrane. They are also gradually drawn in toward the nucleus, until they form a dense fibrous felt about the membrane. Not all the fibres, however, take part in the formation of this felt; many of them remain scattered about, lying in various directions in the cytoplasm. During the folding-over process, a tendency is noted for fibres to approach each other in the neighbourhood of the cell-wall (Fig. 8), so as to form figures suggestive of those shown by Osterhout ('97, Figs. 4, 5), in Equisetum, immediately following the radial stage. Such figures, however, do not in the Larch represent the beginnings of a multipolar spindle, as Osterhout finds to be the case in Equisetum. In these stages there is sometimes a zone con- 
centric to the nuclear membrane, and about midway between that and the cell-wall, in which the fibres are bunched. This zone appears frequently in the preparations from this stage down to that of the equatorial plate, and is suggestive of the kinoplasmic zone figured by Mottier ('97, Figs. 5, 6) in the Lily. But every cell containing such a zone, so far as I have observed, shows a marked shrinking and distortion, and it seems extremely probable that the bunching of the fibres is here an effect of the fixation. Fig. 16, P1. XV, shows a cell at a much later stage, which, in connexion with considerable shrinking and some plasmolysis, shows this outer fibrous zone ; the fibres here are so arranged in several places as to form 'cyto-asters,' suggesting those seen by Mottier ('97, Fig. 28) in Podophyllum, as well as the asters found by Morgan ('96) to be produced in the unfertilized or fertilized eggs of seaurchins and ascidians by treatment with salt solutions of a certain strength, and similar asters found by Mead ('98 $b$ ) in the cytoplasm of unfertilized eggs of Chaetopterus when placed in sea-water. In the two latter cases, the cyto-asters seem to occur as a result of the action of a solution in which the eggs are immersed, the effect being similar, perhaps, to that of a poor fixing-fluid.

During and after the formation of the extra-nuclear felt, there is often a concentration of the granular orange-staining element of the cytoplasm about the nucleus, giving again a vacuolated (not a spongy) appearance to the peripheral cytoplasm. The linin gradually becomes more regularly fibrous, but the fibres are still ragged and granular. The nuclear membrane is still intact, staining deep blue like the fibres. The cell shown in Fig. 9 is considerably shrunken in fixation ; plasmolysis has pulled the nuclear membrane away from the cytoplasm on one side and into the nuclear cavity, where it can be followed, by focusing, through the thickness of the section. There can be no doubt in a case like this that the nuclear membrane is something more than a film due to surface tension between the nuclear sap and the cytoplasm. It is a distinct cell-organ, which retains its 


\section{Allen.-The Early Stages of Spindle-Formation}

continuity in spite of a very considerable displacement and distortion. In favourably stained sections, as that represented in Fig. 8, the cell-wall is orange, and the plasma-membrane blue like the fibres and the nuclear membrane. In optical section, the two membranes and the larger fibres closely resemble each other in colour, density, and thickness. The dark rounded bodies seen in the cytoplasm in Fig. 8 are stained red, like the nucleole. They are doubtless the bodies which have been so frequently described as extra-nuclear nucleoles, and are to be found in many preparations from this stage onwards. They are often, though seemingly not always, in contact with the fibres; there is also a tendency for them to appear more numerously near the periphery of the cell than toward the interior, especially if the peripheral region is much vacuolated. Their number is much greater than that of the blue bodies noticed in earlier stages, so they can hardly be derived from those. Besides, the blue bodies are still occasionally to be seen. On the other hand, the nucleole shows no perceptible diminution in size or density. Its apparent irregularity of shape in the figures is largely due to cohering chromatin masses and linin fibres. There are often to be seen in the liquid surrounding the pollen-mother-cells, and usually clustered about the latter, red-staining bodies of very varying size, exactly resembling those noted in the cytoplasm. This suggests the possibility that both classes of red bodies are drops of unassimilated food substances, perhaps of soluble proteids, which have been precipitated by the fixing-solution. The absence of the membrane on one side of the nucleus in Fig. 10 is due to the fact that the section is cut close to the surface of the nucleus, and is partly tangential to it.

When the extra-nuclear felt is fully formed (Fig. I 2, P1. XV), there is a tendency toward a zonal arrangement of the cytoplasm; outside the felt is a granular region, and between this and the plasma-membrane a zone containing many fibres and little granular material. But fibres can sometimes be seen running out from the inner felt toward the periphery, as 
figured by Belajeff and Strasburger. The nuclear membrane now has a folded or wavy outline and often a granular appearance. The nucleole also shows signs of dissolution; it displays a greater affinity for the orange stain, is vacuolated (Fig. I2) and often collapsed. There is about this time a marked increase in the amount of intra-nuclear fibres, which, however, are still ragged, granular, and wavy.

\section{The Multipolar Spindle.}

After the nuclear membrane disappears (Fig. 13), a distinction may be made for a time between the fibres derived from the cytoplasmic felt and those filling the nuclear cavity, which seem to be wholly or chiefly of nuclear origin. The latter, though now forming a continuous system with the cytoplasmic fibres, are relatively loosely arranged, with large spaces between them, and are still granular, while the cytoplasmic fibres still form a rather compact layer and are much more uniform in thickness. Already a tendency can be noted to a pulling out of the fibres in certain places to form poles. This seems to come about, not under the influence of peripheral fibres, as described by Belajeff, but by an actual outward movement of the ends of some of the fibres of the central mass. At least, the study of a large number of preparations shows no regularity as to the presence of fibres running tangentially from the central mass toward the cell periphery; such fibres are sometimes present, sometimes short or slender, and often wholly absent. I have seen no evidence that these or other peripheral fibres determine the position of the cones of the multipolar figure. The nucleole has disappeared, nearly or quite simultaneously with the disappearance of the membrane. The central fibres soon lose their granular appearance and cannot be distinguished from the outer ones; the whole mass of fibres assumes more and more the appearance of a multipolar spindle. Commonly three or four poles, sometimes indications of one or two more,

- appear in a section. The fibres begin to gather into bundles which run from the chromosomes to the poles. The cell 
drawn at this stage (Fig. I4) is unusually rich in fibrous material, also in 'extra-nuclear nucleoles.' It is very common to find a relatively clear zone surrounding the developing spindle (Figs. 13, I 5, I6); apparently on the dissolution of the nuclear membrane the kinoplasmic weft presses into the cavity, leaving a clear zone between itself and the still present layer of granular cytoplasm.

\section{The Completion of the Spindle.}

The further history of the spindle is essentially what has been described by many of the writers already cited. The arrangement of the fibres into bundles becomes more regular; the fibres forming the bundles are straightened out; the number of poles decreases, apparently as a result of this straightening (Figs. $5^{-1} 8$ ), until the fibres all lie approximately parallel, forming a 'multipolar diarch' figure.

By the time the chromosomes are arranged on the equatorial plate (Fig. I9), the spindle is fully formed. Its fibres converge, not to definite points, but into two polar regions. At first view they seem to end in these regions; but by careful examination and focusing, the fibres, here very lightly stained, may be traced through the polar area into the cytoplasm beyond, where they spread out, still less deeply stained than in the body of the spindle, to form a system of polar radiations. The effect is very much as though the whole bundle of fibres seen in Fig. I 8 had been constricted at two points, one not far from each end, and still allowed to spread out, fan-like, at the ends and in the equatorial region. The fibres can be followed from the polar region out into the peripheral region of the cytoplasm, but only occasionally as far as the plasma-membrane. No indication of any kind of central body has ever been seen in the polar region. Some polar radiations are seen which cannot be traced as continuations of the spindle-fibres; such radiations are more numerous in the diaster stage (Fig. 20), and here also they diverge from a general region rather than from a distinct point, and no central body is to be found. 


\section{CONCLUSIONS.}

The facts observed in the pollen-mother-cell of Larix seem conclusive as to the continuous presence in the cytoplasm, from the very early prophases, of a distinct fibrous system, which, after a series of rearrangements and changes of position, becomes, in conjunction with another set of fibres of nuclear origin, the karyokinetic spindle. A careful study of the preparations leaves no doubt, I think, that the fibres of the reticulum first seen actually become rearranged into a radial system, that this in large part passes into a close extra-nuclear felt, and that the fibres of this felt become eventually the contribution of the cytoplasm to the completed spindle. It is impossible to determine in the mature spindle that any special portion is derived from the cytoplasm or from the nucleus; but each source clearly furnishes an important part. It follows that the active spindle-forming substance, kinoplasm, may first appear, in fibrous form, either in the nucleus or in the cytoplasm; and we may infer that the place of origin of the spindle-fibres, whether nuclear or cytoplasmic, or, as in the present case, partly nuclear and partly cytoplasmic, depends upon the conditions obtaining in, and the relations between, the nucleus and cytoplasm of the cell concerned. The facts accord with this inference; spindles of intra-nuclear origin sometimes occur in connexion with an unusual size of the nucleus, as in the generative cell of Zamia (Webber, '01), or where there is a paucity of cytoplasmic kinoplasm, as in instances cited by Strasburger ('00) in young anthers and nucelli of Lilium and in the growing point of $V i s c u m$; and a greater proportional supply of extra-nuclear kinoplasm may result in spindle-formation such as Němec finds in many vegetative cells, where an extra-nuclear bipolar spindle is completely formed, save for a short equatorial portion, while the nuclear membrane is still intact.

But in spite of the range of variation which has been found in this and in other respects, I think that we may venture to present tentatively, in a general outline, the essential steps in 


\section{Allen.-The Early Stages of Spindle-Formation}

the formation of the spindle in the Spermatophytes, and perhaps in the Pteridophytes as well. Such an outline might be somewhat as follows :-

I. A considerable amount of kinoplasm is present in the cytoplasm, at least by the time of the early prophases, as a more or less uniformly distributed, fibrous reticulum. It will be important to trace still further back the history of the kinoplasm ; but no observations yet made seem to throw any light upon this problem. Indeed, very few observers have followed spindle-formation back even to as early a point as this ; but Miss Williams ('99) and Miss Byxbee ('00) find that the spindle primordium ('Anlage') develops from an early cytoplasmic meshwork.

2. The fibres of the reticulum become so arranged as to extend radially from the nuclear membrane out into the cytoplasm. It seems quite likely that this results partly from a radial pulling out of the meshes; but very probably there is also an actual growth in length of the fibres composing the reticulum, so that many of them finally reach to the plasmamembrane. Several authors have been cited who find a radial arrangement of fibres at this period.

3. As a result of a folding-over of the radial fibres, a felt is formed just without the nuclear membrane.

4. The nuclear membrane and the nucleole disappear, and the nuclear cavity also becomes occupied by a set of fibres.

5. The peripheral fibres of the central mass become pulled out to form several or many cones.

6. The fibres, nuclear and cytoplasmic, are gathered into bundles, forming a multipolar figure.

7. The number of poles is reduced, by fusion, to two.

The felted stage and the succeeding steps in the process have been so often noted that there can be no doubt in these later stages as to the regular course of events. Osterhout's description of the formation of the cones in Equisetum by a grouping of radial fibres, which in turn proceed from a felted layer, suggests the interesting possibility of a constant difference in the succession of events as between Seed Plants 
and Pteridophytes; the testing of this possibility must be left to future research.

So far as I know, no study has been made in vegetative cells of the stages previous to the appearance of the felt. The difference between ' multipolar polyarch' and 'multipolar diarch' spindles seems, from the descriptions of Strasburger (00) and Miss McComb ('00), to result from the fact that in the latter form the felted layer, instead of giving rise to spindlecones on all sides of the nucleus, first becomes aggregated into polar caps, and so the cones arise in two groups. Strasburger shows that the extreme cases are connected by transitional forms ; and Němec ('99 $a$, '99c, '99 $d$ ) thinks that by artificial changes in the physical conditions of the cell a polyarch instead of a diarch 'Anlage' may be produced. He also finds that in normal mitoses in many vegetative cells the nuclear membrane persists until after the spindle 'Anlage' has become sharply bipolar; and, as I have suggested, this is what we might expect if the cytoplasm furnishes a larger proportion of the spindle-forming fibres than is commonly the case in spore-mother-cells. The differences between vegetative and reproductive cells therefore appear to be in matters of detail; and spindle-formation in both, so far as investigated, agrees with the general scheme just outlined.

Few of the details are known as yet in any case of intranuclear spindle-formation; but the above outline would certainly require modification in order to fit these cases, at least in so far as concerns the place of initial appearance and activity of the kinoplasm. That a certain parallelism, however, holds between the two methods is shown by Murrill's observation that in the first segmentation of the egg of Tsuga, an intra-nuclear multipolar spindle occurs, which becomes bluntly bipolar; and by Strasburger's ('00) description, in vegetative cells of Lilium and Viscum, of an intra-nuclear multipolar diarch 'Spindel-Anlage.'

Several cases have been noticed which seem to diverge still more greatly from the usual history of the building of the spindle. Such are its formation entirely out of the nucleole, 
according to Stevens ('98), in the pollen-mother-cell of Asclepias; the origin of the fibres, as described by Murrill ('00), in the central cell of the archegonium of Tsuga, from two unequal polar kinoplasmic masses; and the instance described by Miss Ferguson ('01) in the division of the generative nucleus of Pinus, where the spindle arises as a cone of fibres from a single cytoplasmic condensation below the nucleus, the latter lying close to the upper boundary of the cell. But such cases seem to be quite unusual, and it may be that further investigation will harmonize these with what are apparently more typical instances of spindle-formation.

I have spoken of the cytoplasm in the early stages as composed apparently of a kinoplasmic network with empty meshes. The spaces between the fibres are of course filled, as the turgor of the cell shows, and it seems improbable that they are occupied only by a lifeless cell-sap. In later stages there is plainly an orange-staining inter-fibrous substance, granular rather than alveolar in structure, but in the earliest preparations I have not succeeded, by any variation of the staining process, in finding a trace of colour in the cytoplasm outside of the fibres. I have also been convinced from a careful study of Flemming and Vom Rath preparations that the fibrous appearance is not a precipitation result. Still earlier preparations of the developing male cones will be necessary to throw further light upon the cytoplasmic structures.

As has been said, the great preponderance of evidence is opposed to the existence of centrosomes in the higher plants ; and conditions in the Larch seem to justify us in saying that here the possibility of a centrosome, in the sense of a directive organ, is excluded. Not only is no such body to be seen at any stage, but, if my observations are at all correct, there is no room to assume its operation. The fibres change their position without reference to any centre or to any definite number of centres. If centrosomes determine the radial arrangement, for example, we must imagine either as many centrosomes as there are radial fibres, or else a single centrosome somewhere within the nucleus; and when the multipolar 
figure appears, we must assume either that the many centrosomes have now fused into relatively few, or that the one has passed from the nucleus out into the cytoplasm and there has divided into ten, twelve, fifteen, or twenty. It seems evident from such considerations that the assumption of the possible presence of organs like the animal centrosome in the cells in question involves an ignoring of the best-established facts.

The impression is given by a study of the arrangements and rearrangements of the kinoplasm that the activities concerned in the formation of the spindle centre in, or have reference to, the nucleus. Such an impression led Nermec ('98 b) to the hypothesis that the nucleus, in cells without a centrosome, is 'homo-dynamic' with the centrosome where it occurs. It is true that the ultimate function of the fibres, in the completed spindle, has reference to certain nuclear constituents - the chromosomes. From the generally accepted notion of the nucleus as the bearer of hereditary qualities, it follows, too, that that organ is the ultimate source of the stimuli which determine the synthetic processes of the cell ; and this hypothesis is borne out by a considerable mass of experimental evidence (Wilson, '00 ; Gerassimow, '01 ; \&c.). It is quite possible, therefore, to suppose that the ultimate directive agencies for the growth and even for the arrangement of the kinoplasm, as of other cell-constituents, may finally be traced to the nucleus. $\Rightarrow$ But this is very different from saying that the present seat of the energy which is manifested in the movement of a particular fibre is within the nucleus; and it seems to me that the facts which we have been considering are inexplicable on the basis of the latter assumption. It might be imagined that the nucleus, acting like an immense centrosphere, should produce some such system of rays as appears in Fig. 6 ; but that it should, by exerting an influence at all comparable to the supposed action of a central body, be directly concerned in the metamorphosis of the early reticulum into a radial system, or in developing from the latter a felt, a multipolar or a bipolar spindle, seems quite inconceivable. 
All of my observations are opposed to the notion that the kinoplasmic fibres are only 'lines of force,' or that they are, as Farmer ('95 $b$ ) expresses it, simply hyaline protoplasm which has become strained along such lines of force. The appearance of the fibres throughout their history, their staining properties, their powers of movement and contraction, all set them off as distinct from the surrounding cytoplasm, and argue in favour of their chemical and physical differentiation. The well-known formation of asters about the blepharoplasts points in the same direction; for the same organs later form cilia which certainly closely resemble, if they are not essentially identical with, the intracellular fibres. Farmer ('95 $b$, p. 475) found that the fibres of the polar aster in Fossombronia extended as stiff projections beyond the broken edge of a cell which had been injured in cutting. In some preparations of my own of the dividing pollen-mother-cells of Lilium, there are numerous cases in which, after the first nuclear division and the formation and splitting of the cell-plate, some of the fibres of the central spindle may still be seen stretching, as densely stained strands, across the gap between the daughter-cells. Such facts appear consistent only with the actual existence of the fibres as differentiated structures.

This specialized fibrous constituent of the cytoplasm seems to be, as has often been pointed out, the more active element of the cell; the fibres in many ways display energy; they change their position in the cell; they bend and straighten themselves ; they extend into the nuclear cavity, are attached to the chromosomes, and appear to pull these bodies out into close proximity to the nuclear membrane; when the latter disappears, the fibres arrange themselves into a figure of definite form, the bipolar spindle; they apparently pull the chromosomes into the equatorial plate, and from this situation draw the daughter-chromosomes toward the poles. These activities suggest an analogy, if not a close relationship, between the fibres in question and the cilia of motile cells, and perhaps even a relationship with the contractile elements of muscle-fibres. Since, as has been noted, there is no 
evidence that the activity of the fibres is under the influence of a central body, or, directly at least, under that of the nucleus, it follows as the most plausible explanation that the fibres are self-motile-that is, that they are themselves the seat of the energy which they manifest. If, then, the central body, where it exists, really has the function of directing the processes of spindle-building, this particular function seems, in the higher plants, to have been transferred to the fibres themselves.

Other functions which have been ascribed to the central body-either the attraction-sphere with its included centrosome, or one of these parts, the sphere or centrosome, occurring without the other-must also be served, in the Seed Plants, by other organs of the cell. Such functions may be included under three heads: the central body has been conceived as furnishing a reserve supply of kinoplasm; as serving as a centre for the building of kinoplasmic fibres; and as providing for the fibres a point of insertion-the spindle-pole.

As to the first function, Boveri ('88) found that the attraction-sphere, exclusive of its central granule, is a mass of kinoplasm which is used, wholly or partly, in the building of the aster. Other bodies than the attraction-sphere, however, have been found to serve, in various cells, the same purpose-'archoplasm-spheres,' the 'Nebenkern' of animal spermatozoa, and, as Strasburger has long contended ('00, pp. I $24 \mathrm{ff}$., for résumé), the nucleole. Watasé ('93) has sought to show that centrosomes, microsomes, the ' $Z$ wischenkörper' of animal cells and the cell-plates of plants are all aggregations of a similar cytoplasmic material. The experiments of Hottes and Nermec show that, under the influence of stimuli which retard the activity of the kinoplasmic fibres, the fibrous substance tends to round up into bodies of various size, from that of granules or ' cyto-microsomes' to that of 'extra-nuclear nucleoles'; and Hottes shows that at higher temperatures the extra-nuclear nucleoles seem to be transformed into fibres, while cooling checks kinoplasmic activity and induces the re-formation of nucleolar bodies. Němec ('01) has shown, 
too, that in the higher plants other extra-nuclear masses, probably of kinoplasmic nature, sometimes occur. These facts, as well as the frequent appearance under normal conditions, at certain stages of mitosis, of extra-nuclear nucleoles, suggest that in plant-cells this function of the attractionsphere is served by other organs, very probably in part at least by the nucleole, in part too, perhaps, by other and less permanent bodies.

The second function of the central body, that of furnishing a centre for the formation of kinoplasmic fibres, seems to be rendered unnecessary in the cells of the higher plants; at least the evidence shows that spindle-formation in these plants may go on in the absence of a specialized organ which acts as a centre. It is true, we may think of a great number of centres of growth scattered throughout the cytoplasm; but this conception is radically different from that of the centrosome, and is perhaps, in the present state of knowledge, one of little real value. On the basis of observed facts, it seems safe only to say that the forces involved in fibreformation, instead of being centred about one or two points, are diffused throughout the cell. This is in harmony with the fact already noticed, that, after the formation of the fibres, their activities have no reference to any centre or to any limited number of centres.

The other office of the central body, that of serving as a point of insertion for the spindle-fibres, seems also to be dispensed with in many instances. Many figures found in plant-cells recall the barrel-shaped polar spindles of Ascaris (Boveri, '87; Häcker, '97). Very similar spindles are found by Fairchild ('97) in Basidiobolus, in which case, as in Ascaris, the fibre-bundles end in granules; a barrel-shaped spindle is described in Spirogyra by many writers (see Strasburger, '88, and Mitzkewitsch, '98); and among the Seed Plants, spindles which remain throughout their history blunt or barrel-shaped are described by Strasburger ('88) in the endosperm of Dictamnus; by Mottier '(97) in the pollen-mothercell of Podophyllum; in that of Convallaria by Wiegand ('99); 
in the division of the central archegonial cell of Cycas by Ikeno ('96, '98), of Pinus by Blackman ('98), and of Zamia by Webber ('01); in the segmentation of the eggs of Cycas and Ginkgo by Ikeno ('98, '01), and of those of Cephalotaxus by Arnoldi ('00); and in the cells of wounded potato tubers by Nermec (' $99 c)$. In the division of the generative nucleus of Potamogeton, Wiegand ('99) finds that one pole, attached to the cell-wall, is very broad, the other sharp. In the Larch we have seen that the fibres converge to a limited polar region, but not to a definite point.

Evidently, if, by their contraction, the spindle-fibres are to pull apart the daughter-chromosomes, they must have some attachment or anchorage for their polar ends. This purpose we may imagine to be well served by a special body to which they all converge, provided that body have itself some means of attachment; but the instances just cited show that the cells of many organisms, including those of higher plants, have secured means of insertion for their spindle-fibres in the absence of such a definite body, and often without even a marked convergence toward a polar region. Strasburger ('00) shows that in some cases a point of attachment is found in the plasma-membrane; but in many others, the fibres seem to end in the cytoplasm, whose substance in this region we must suppose is adapted to furnish an anchorage for the contracting fibres.

It would seem, then, that the cells of the higher plants have either found other organs to replace the centrosome, or that they have found means to dispense with its functions entirely and to arrive at substantially the same results by quite different methods. I shall not attempt to criticize the centrosome theory except as applied to the higher plants ; but it is evident that the whole centrosome question for the animal cell is at present an open one; and such problems as the persistence of this organ through succeeding cell generations and its significance in nuclear division are still far from settled (Conklin, '98; Gardiner, '98; Mead, '98 a).

As to the energy manifested by the kinoplasmic fibres, it 
seems highly probable that it is located within the fibres themselves, and that its source is to be sought in chemical transformations-destructive metabolism-occurring in the substance of the fibre concerned. Since the volume of the kinoplasm remains relatively constant during considerable periods, constructive metabolism must go on side by side with the destructive process ; the kinoplasm, then, in a period of activity, is to be thought of as in a condition of more or less rapid change; it is being built up at the expense of some of the surrounding non-fibrous substance, perhaps of already living cell-constituents, perhaps of non-living but complex foods. The energy displayed by a particular fibre represents the difference between the energy of formation of the food which it receives, and that of the waste products which result from the destruction of its substance. It then becomes possible to define an active kinoplasmic fibre as the area within which certain energy-changes are occurring; and the mass of the fibre is the sum of the masses of the substances within that area at the present moment, some of which are being built up, some being torn down, while still others may remain for a greater or less period unchanged.

This notion of the nature of kinoplasm seems to be, as far as it goes, identical with the suggestion of Wilson ('95), when he defines a cell-organ as 'a differentiated area of the cellsubstance in which a specific form of chemical change occurs.' From this point of view, too, it is correct to say that the spindle-fibres are expressions of forces at work within the cell; but while admitting the possibility of defining certain organs from the point of view of the energy-changes occurring in them, I think it is important to insist upon the mass of evidence already referred to which points to the existence of a distinct fibre-substance. The fibres, that is, are something more than paths or lines of force, or mere expressions of strains and stresses; they are organs built up of a substance or of substances with distinctive chemical and physical properties, which properties determine the power of the organ to do particular kinds of work. The organ owes its existence 
to certain chemical processes, and it does its work by means of the energy set free by these or by other chemical processes ; but it is also a machine, adapted by its structure to utilize in a definite way the energy so liberated.

The investigations here described were begun at the suggestion of Professor R. A. Harper, and have been carried on with the continued assistance of his direction and criticism.

MADISON, Wisconsin.

June $\mathrm{I} 7,1902$. 


\section{Allen.--The Early Stages of Spindle-Formation}

\section{LiteratuRE Cited.}

ANDREWS, F. M. ('01): Karyokinesis in Magnolia and Liriodendron, with special reference to the behaviour of the chromosomes. Beih. z. Bot. Centralbl., Bd. xi, p. I34.

Arnoldi, W. ('00): Beiträge zur Morphologie der Gymnospermen. III. Flora, Bd. lxxxvii, p. $4^{6}$.

Atkinson, G. F. ('99): Studies on reduction in plants. Bot. Gaz., vol. xxviii, p. I.

Belajeff, W. ('94) : Zur Kenntniss der Karyokinese bei den Pflanzen. Flora, Bd. lxxix, p. 43 .

Blackman, V. H. ('98): On the cytological features of fertilization and related phenomena in Pinus silvestris, L. Phil. Trans. Roy. Soc., B, vol. cxc, p. 395 .

Boveri, T. ('87): Zellenstudien, Heft I. Jena. ('88) : Zellenstudien, Heft 2. Jena.

Byxbee, E. S. ('00): The development of the karyokinetic spindle in the pollenmother-cells of Lavatera. Proc. Cal. Acad. Sci., 3rd ser., Bot., vol. ii, p. 63 .

CAMpbell, D. H. ('95): The structure and development of the mosses and ferns. New York.

ConkLin, E. G. ('98) : The asters in fertilization and cleavage (abstract of paper). Sci., N. S., vol. vii, p. 224.

DAvis, B. M. ('99): The spore-mother-cell of Anthoceros. Bot. Gaz., vol. xxviii, p. 89 .

('01): Nuclear studies on Pellia. Ann. of Bot., vol. xv, p. 147.

Debskr, B. ('98): Weitere Beobachtungen an Chara fragilis, Desv. Jahrb. f. wiss. Bot., Bd. xxxii, p. 635 .

Demoor, J. ('95): Contribution à l'étude de la physiologie de la cellule. Arch. d. Biol., tom. xiii, p. 163. Cited by Němec, '99 $d$.

DugGar, B. M. ('99): On the development of the pollen-grain and the embryosac in Bignonia venusta. Bull. Tor. Bot. Club, vol. xxvi, p. 89 . Symplocarpus foetidus and Peltandra undulata. Bot. Gaz., vol. xxix, p. 8I.

FaIRChild, D. G. ('97): Ueber Kerntheilung und Befruchtung bei Basidiobolus ranarum, Eidam. Jahrb. f. wiss. Bot., Bd. $\mathrm{xxx}$, p. 285.

FARMER, J. B. ('93): On nuclear division in the pollen-mother-cells of Lilium Martagon. Ann. of Bot., vol. vii, p. 392.

('94): Studies in Hepaticae: On Pallavicinia decipiens, Mitten. Ann. of Bot., vol. viii, p. 35 .

('95 a) : Spore-formation and karyokinesis in Hepaticae. Ann. of Bot., vol. ix, p. $3^{6} 3$.

$(956)$ : On spore-formation and nuclear division in the Hepaticae. Ann. of Bot., vol. ix, p. 469 .

('95c): Further investigations on spore-formation in Fegatella conica. Ann. of Bot., vol. ix, p. 666. 
FARMer, J. B. ('95 d): Ueber Kerntheilung in Lilium-Antheren, besonders in Bezug auf die Centrosomen-Frage. Flora, Bd. $1 x x x$, p. 56 .

Ferguson, M. C. ('01): The development of the pollen-tube and the division of the generative nucleus in certain species of pines. Ann. of Bot., vol. $\mathrm{xv}, \mathrm{p}$. I93.

Fullmer, E. L. ('98): Cell-division in pine seedlings. Bot. Gaz., vol. xxvi, p. 239 .

('99): The development of the microsporangia and microspores of Hemerocallis fulva. Bot. Gaz., vol. xxviii, p. 8I.

GARDINER, E. G. ('98): The growth of the ovum, formation of the polar bodies, and the fertilization in Polychoerus caudatus. Journ. of Morph., vol. xv, p. 73 .

Gerassimow, J. J. ('01): Ueber den Einfluss des Kerns auf das Wachsthum der Zelle. Moscow.

GUIGNARD, L. ('91 $a$ ): Sur l'existence des 'sphères attractives' dans les cellules végétales. Compt. Rend., tom. cxii, p. 539 .

('91 $b)$ : Sur la nature morphologique du phénomène de la fécondation. Compt. Rend., tom. cxii, p. $\mathbf{1}_{220}$.

('91c): Nouvelles études sur la fécondation. Ann. Sci. Nat., Bot., $7^{\ominus}$ sér., tom. xiv, p. I63.

('97 a): Les centrosomes chez les végétaux. Compt. Rend., tom. exxv, p. II 48 .

('97 b) : Les centres cinétiques chez les végétaux. Ann. Sci. Nat., Bot., $8^{\circ}$ sér., tom. vi, p. I 77 .

('98): Centrosomes in plants. Bot. Gaz., vol. xxv, p. $5^{8}$.

HäCKer, V. ('97): Ueber weitere Uebereinstimmungen zwischen den Fortpflan: zungsvorgängen der Tiere und Pflanzen. Biol. Centralbl., Bd. xvii, p. 689.

HoF, A. C. ('98): Histologische Studien an Vegetationspunkten. Bot. Centralbl., Bd. lxxvi, p. ${ }_{5}$.

IKEno, S. ('96): Note préliminaire sur la formation de la cellule de canal chez le Cycas revoluta. Bot. Mag. Tokyo, tom. x, p. 287. Cited by Webber, '01, p. 89.

('98): Untersuchungen über die Entwickelung der Geschlechtsorgane und den Vorgang der Befruchtung bei Cycas revoluta. Jahrb. f. wiss. Bot., Bd. xxxii, p. 557 .

('01): Contribution à l'étude de la fécondation chez le Ginkgo biloba. Ann. Sci. Nat., Bot., $8^{\triangleright}$ sér., tom. xiii, p. 305.

Juel, H. O. ('97): Die Kerntheilungen in den Pollenmutterzellen von Hemerocallis fulva und die bei denselben auftretenden Unregelmässigkeiten. Jahrb. f. wiss. Bot., Bd. xxx, p. 205.

LAwson, A. A. ('98): Some observations on the development of the karyokinetic spindle in the pollen-mother-cells of Cobaea scandens, Cav. Proc. Cal. Acad. Sci., 3rd ser., Bot., vol. i, p. 169 .

('00): Origin of the cones of the multipolar spindle in Gladiolus. Bot. Gaz., vol. xxx, p. 145 .

МсСомв, А. ('00): The development of the karyokinetic spindle in vegetative cells of higher plants. Bull. Tor. Bot. Club, vol. xxvii, p. $45 \mathrm{I}$.

MEAD, A. D. ('98 a): The rate of cell-division and the function of the centrosome.

Biol. Lect., I896-7, Mar. Biol. Lab., p. 203. Boston. 
MEAD, A. D. ('98b): The origin and behaviour of the centrosomes in the annelid egg. Journ. of Morph., vol. xiv, p. I8r.

Mitzkewitsch, L. ('98): Ueber die Kerntheilung bei Spirogyra. Flora, Bd. lxxxv, p. $8 \mathrm{I}$.

Moore, J. E. S. ('94): Some points on the origin of the reproductive cells in Apus and Branchipus. Quart. Journ. Micr. Sci., vol. v, p. 35. Cited by Häcker, ' 97 , p. 722 .

Morgan, T. H. ('96): The production of artificial archoplasmic centres (abstract of paper). Sci., N. S., vol. iii, p. 59.

Mottier, D. M. ('97) : Beiträge zur Kenntniss der Kerntheilung in den Pollenmutterzellen einiger Dikotylen und Monokotylen. Jahrb. f. wiss. Bot., Bd. $x x x$, p. 169 .

('98): Ueber das Verhalten der Kerne bei der Entwickelung des Embryosacks und die Vorgänge bei der Befruchtung. Jahrb. f. wiss. Bot., Bd. xxxi, p. 125.

Murrill, W. A. ('00): The development of the archegonium and fertilization in the hemlock spruce (Tsuga Canadensis, Carr). Ann. of Bot., vol. xiv, p. $5^{8} 3$.

NĚmec, B. ('97): Cytologische Untersuchungen an Vegetationspunkten der Pflanzen. Sitzber. d. kön. böhm. Ges. d. Wiss., Prag, 1897, Bd. xxxiii, p. 25.

('98 a): Ueber die Ausbildung der achromatischen Kerntheilungsfigur im vegetativen und Fortpflanzungsgewebe der höheren Pflanzen. Bot. Centralbl., Bd. lxxiv, p. I.

('98 b): Ueber das Centrosoma der tierischen Zellen und die homodynamen Organe bei den Pflanzen. Anat. Anz., Bd. xiv, p. 569 .

('99 a) : Zur Physiologie der Kern- und Zelltheilung. Bot. Centralbl.,

Bd. lxxvii, p. 24I.

('99b): Ueber die karyokinetische Kerntheilung in der Wurzelspitze von Allium cepa. Jahrb. f. wiss. Bot., Bd. xxxiii, p. 3 I 3 .

('99c) : Ueber Kern- und Zelltheilung bei Solanum tuberosum. Flora, Bd. lxxxvi, p. 2 I 4 .

- (99d): Ueber den Einfluss niedriger Temperaturen auf meristematische Gewebe. Sitzber. d. kön. böhm. Ges. d. Wiss., I899, Bd. xii, p. I.

('01): Ueber centrosomähnliche Gebilde in vegetativen Zellen der Gefässpflanzen. Ber. d. deut. bot. Ges., Bd. xix, p. 301 .

Osterhout, W. J. V. ('97) : Ueber Entstehung der karyokinetischen Spindel bei Equisetum. Jahrb. f. wiss. Bot., Bd. xxx, p. I59.

Rosen, F. ('95): Beiträge zur Kenntniss der Pflanzenzellen. Cohn's Beitr. z. Biol. d. Pflanzen, Bd. vii, p. 225.

SARGant, E. ('97): The formation of the sexual nuclei in Lilium Martagon. II. Spermatogenesis. Ann. of Bot., vol. xi, p. 187.

Schaffner, J. H. ('98): Karyokinesis in the root-tips of Allium cepa. Bot. Gaz., vol. xxvi, p. 225 .

('01): A contribution to the life-history and cytology of Erythronium. Bot. Gaz., vol. xxxi, p. 369 .

Schniewind-Thies, J. ('01): Die Reduktion der Chromosomenzahl und die ihr folgenden Kernteilungen in den Embryosackmutterzellen der Angiospermen. Jena. 


\section{in the Pollen-Mother-Cells of Larix.}

Smith, R. W. ('00a): The structure and development of the sporophylls and sporangia of Isoëtes. Bot. Gaz., vol. xxix, p. 225.

$\left({ }^{\prime} 00 b\right)$ : The achromatic spindle in the spore-mother-cells of Osmunda regalis. Bot. Gaz., vol. $\mathrm{xxx}, \mathrm{p} .36 \mathrm{I}$.

Stevens, W. C. ('98): The behaviour of kinoplasm and nucleolus in the division of the pollen-mother-cells of Asclepias Cornuti. Kansas Univ. Quart., vol. vii, p. $7 \%$.

Strasburger, E. ('80): Zellbildung und Zelltheilung. Dritte Auf. Jena. ('88) : Ueber Kern- und Zelltheilung im Pflanzenreiche. Hist. Beitr., Bd. i. Jena.

xxviii, p. I5I.

('95): Karyokinetische Probleme. Jahrb. f. wiss. Bot., Bd.

('00): Ueber Reduktionstheilung, Spindelbildung, Centrosomen und Cilienbildner im Pflanzenreich. Hist. Beitr., Bd. vi. Jena.

('01) : Einige Bemerkungen zu der Pollenbildung bei Asclepias. Bèr. d. deut. bot. Ges., Bd. xix, p. $45^{\circ}$.

Watast, S. ('93): Homology of the centrosome. Journ. of Morph., vol. viii, p. 433.

Webber, H. J. ('01): Spermatogenesis and fecundation of Zamia. U. S. Dept. of Agric., Burean of Plant Industry, Bull. No. 2.

WiEgand, K. M. ('99): The development of the microsporangium and microspores in Convallaria and Potamogeton. Bot. Gaz., vol. xxviii, p. 328.

Williams, C. L. ('99): The origin of the karyokinetic spindle in Passiflora coerulea, Linn. Proc. Cal. Acad. Sci., 3rd ser., Bot., vol. i, p. 189.

Wilson, E. B. ('95): Archoplasm, centrosome and chromatin in the sea-urchin egg. Journ. of Morph., vol. xi, p. 443. York. 


\title{
EXPLANATION OF FIGURES IN PLATES $\mathrm{XIV}$ and $\mathrm{XV}$.
}

\author{
Illustrating Mr. Allen's paper on the Pollen-Mother-Cells of Larix.
}

All the figures were drawn with the aid of the camera lucida, and with a Zeiss apochromatic $2 \mathrm{~mm}$. objective, I.30 apert.; all except Fig. 4, Pl. XIV, with compens. oc. 8 ; Fig. 4 , with compens. oc. I 2.

\section{PLATE XIV.}

Fig. I. Cross-section of pollen-mother-cell of Larix europaea, DC., material gathered and fixed October 24 ; very early prophases, showing fibrous network in the cytoplasm.

Fig. 2. Cell fixed March I5 following; an inter-fibrous material is ncw present.

Fig. 3. Somewhat later stage, with rather thick cell-wall.

Fig. 4. Small part of section of cell at same stage, cut tangentially to the nucleus; membrane not visible; the dark rounded bodies are chromatin, the lighter shaded masses linin; fibres can be traced from the chromatin bodies into continuity with the cytoplasmic network.

Fig. 5. A cell from the same section as Figs. 3 and 4 ; the cytoplasmic fibres have taken on a radial arrangement.

Fig. 6. Radial stage, fibres running from nuclear membrane to plasma membrane.

Fig. 7. Beginning of folding-over of fibres.

Fig. 8. Fibres are gathering into felt just outside nucleus; many extra-nuclear nucleoles present.

Fig. 9. A cell somewhat shrunken, with the nuclear membrane plasmolysed and pushed inward.

Figs. Io and II. Later stages in the formation of the felt.

\section{PLATE XV.}

Fig. I 2. The completed felt; nuclear membrane much folded, probably on the point of dissolution; nucleole vacuolated.

Fig. I3. The nuclear membrane has disappeared; nuclear cavity contains granular fibres of nuclear origin; the outer fibres are being oriented to form the cones of the multipolar spindle.

Figs. $I_{4}$ and I $_{5}$. Later stages in the formation of the multipolar spindle. In Fig. I5 the fibres are gathered into bundles which run from the poles to the chromosomes.

Fig. 16. A multipolar figure; the cell somewhat shrunken and plasmolysed; a peripheral zone containing fibres and irregular ' cyto-asters.'

Fig. 17. The fibres becoming straightened out and parallel; a transition to the bipolar spindle.

Fig. I8. A ' multipolar diarch' stage.

Fig. I9. A completed spindle in the equatorial plate stage, showing polar radiations.

Fig. 20. The diaster stage; a few especially dense fibres or strands in the central spindle; the polar radiations very numerous. 

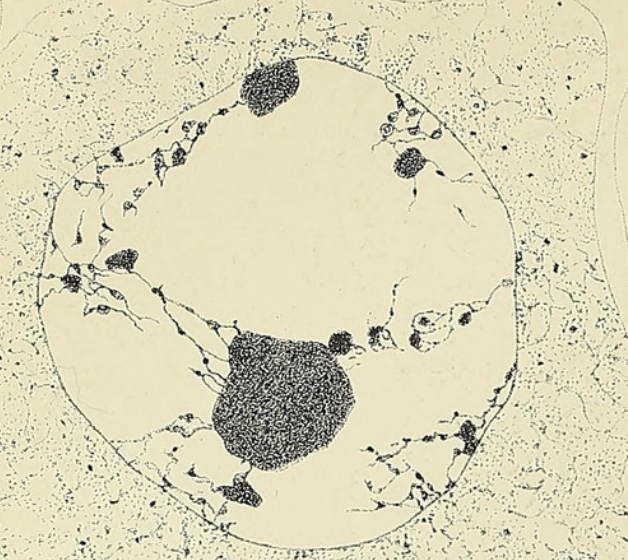

Fig. 2 .
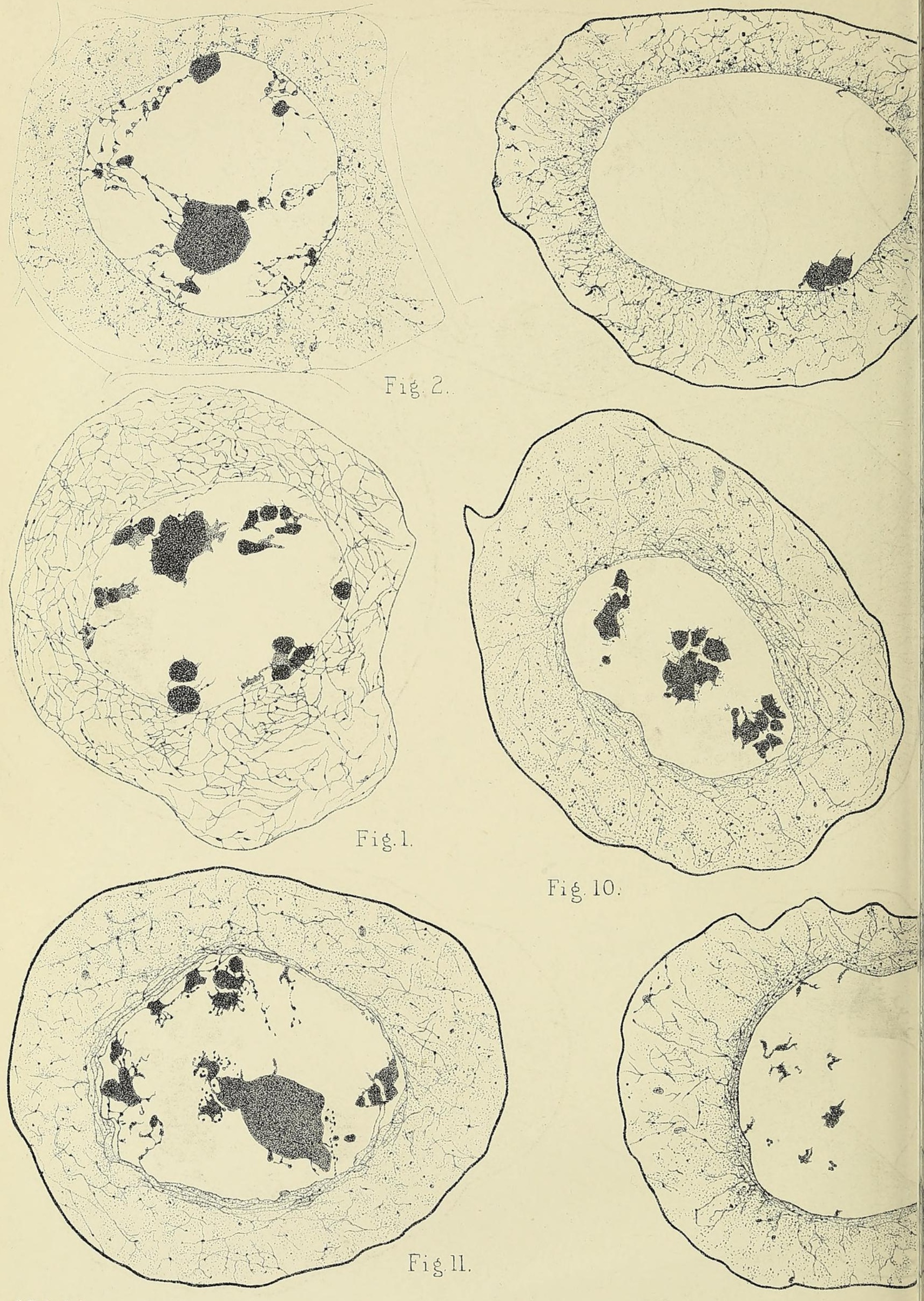

ALLEN.- POLLEN-MOTHER-CELLS OF LARIX. 
Vol.XVII PL.XIV.

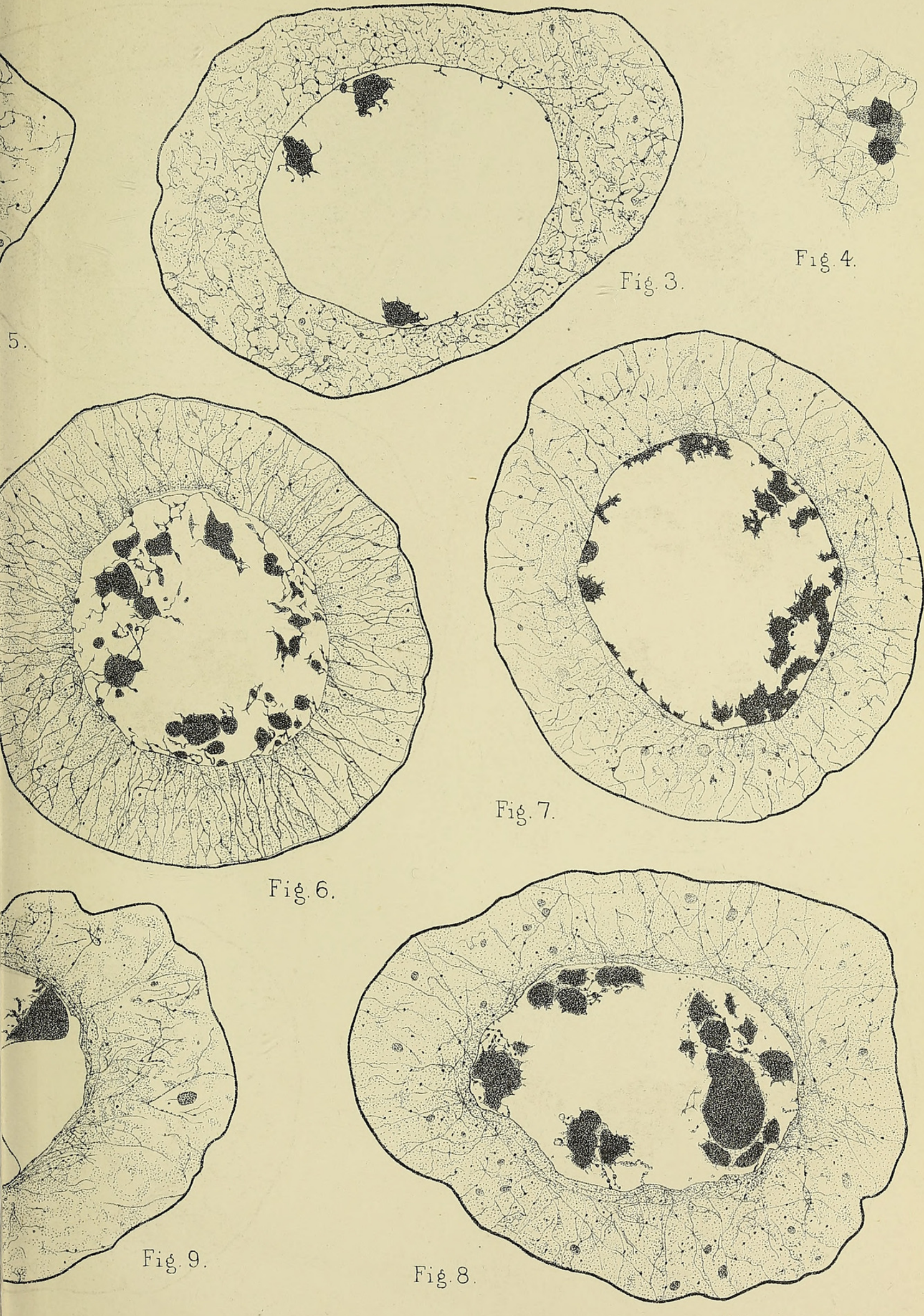

Univer sity Press, Oxford. 

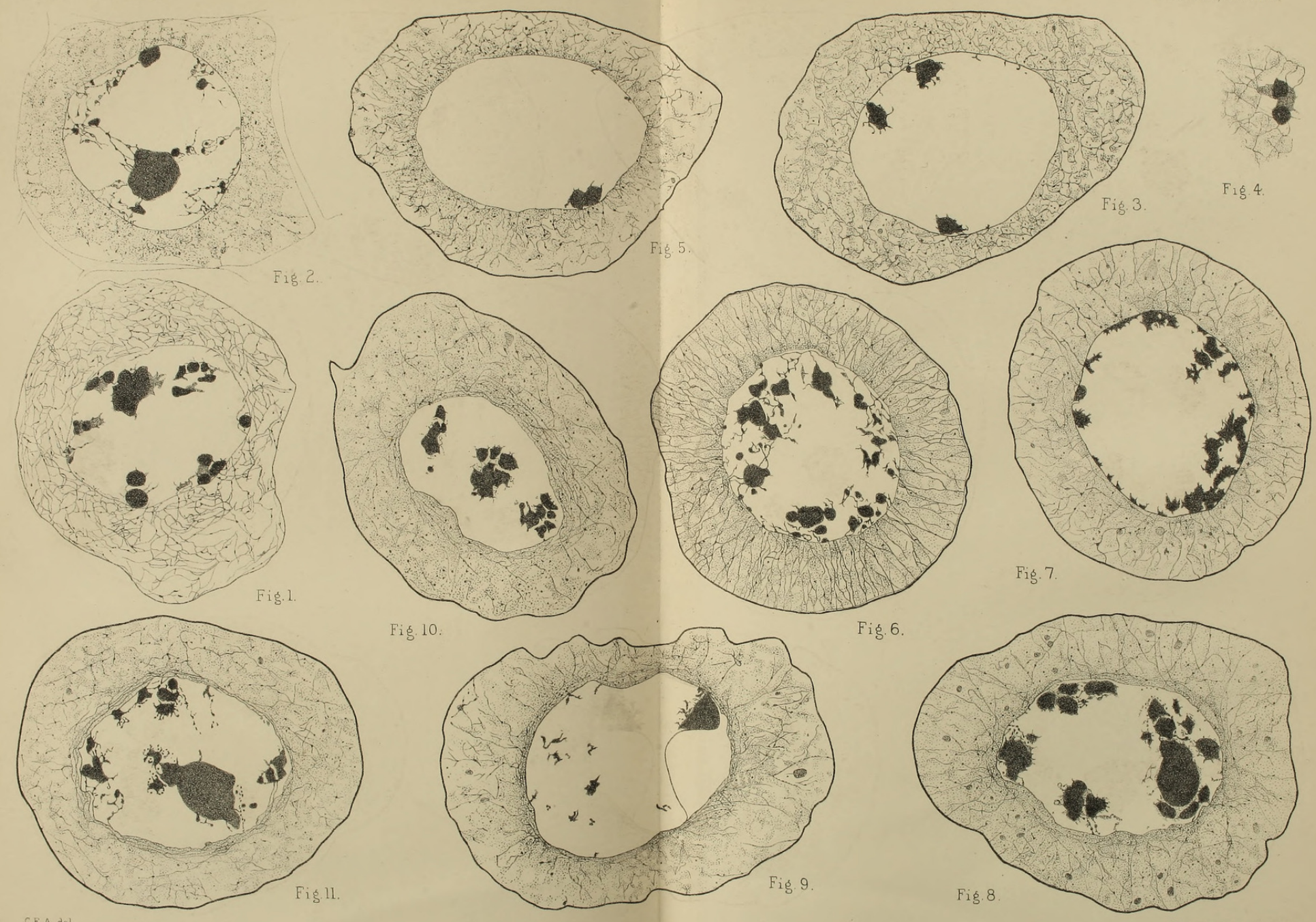

Fiǵ. 6.
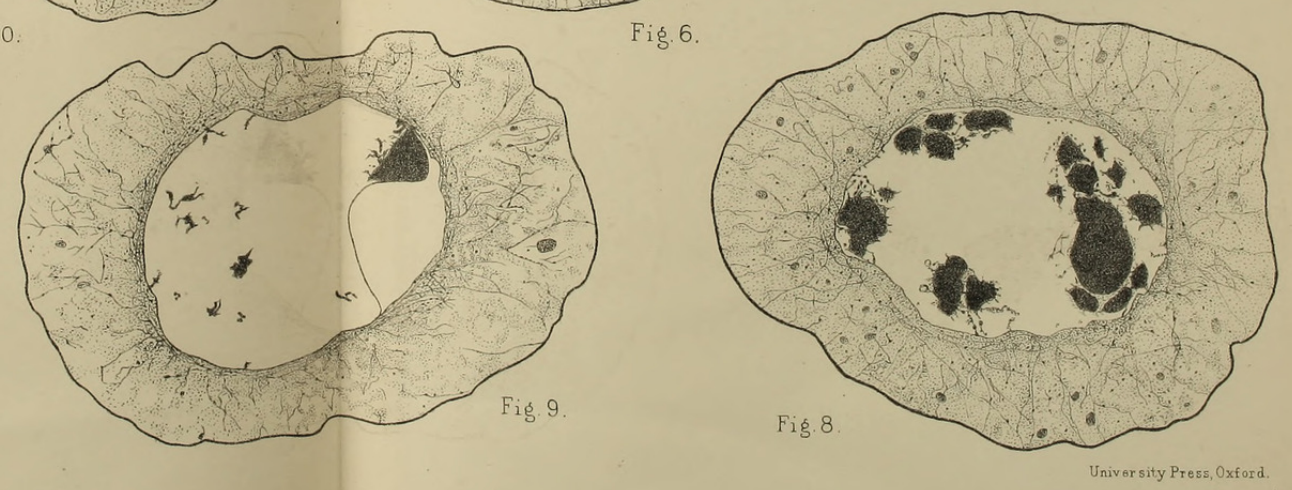
Annals of Botany.

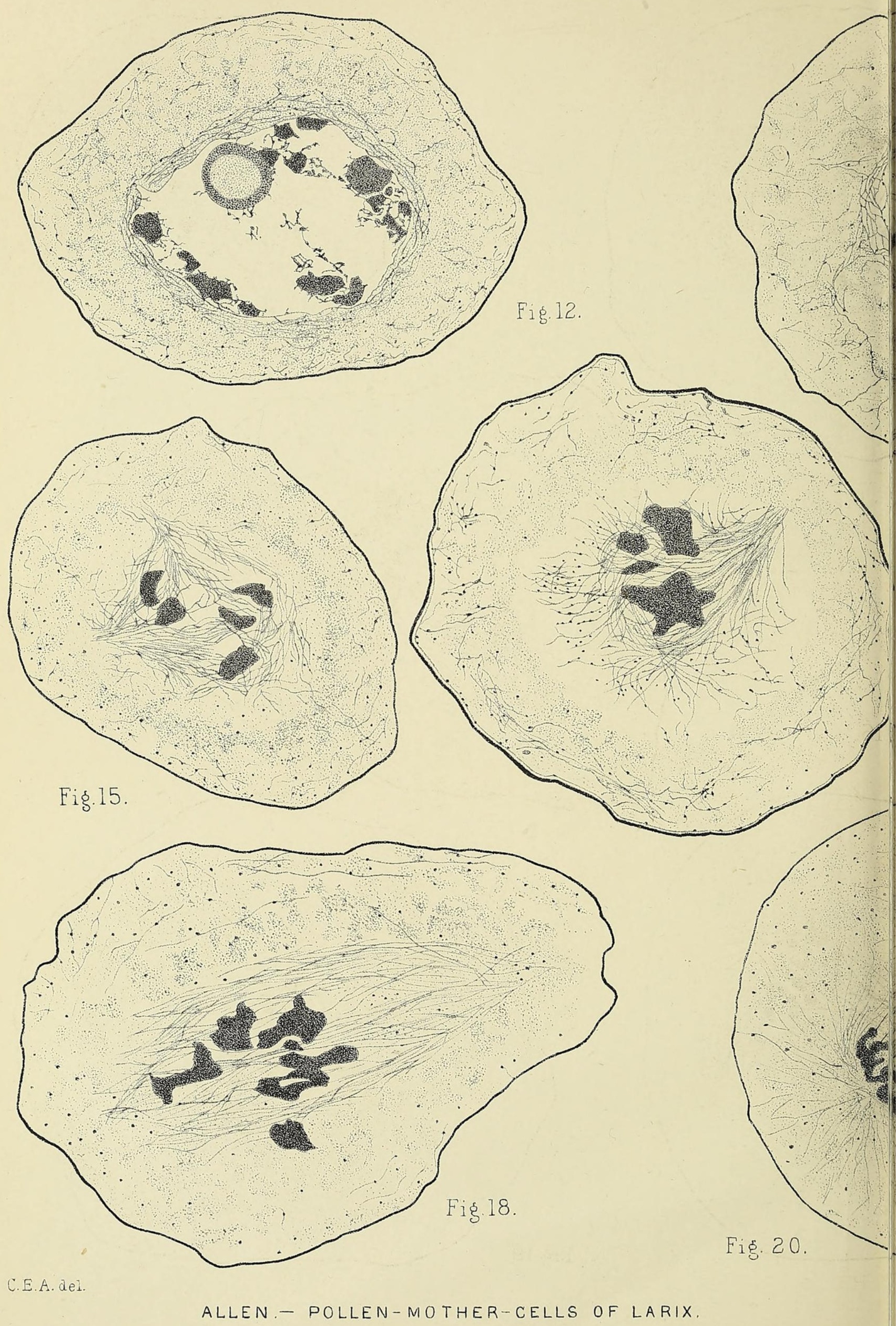




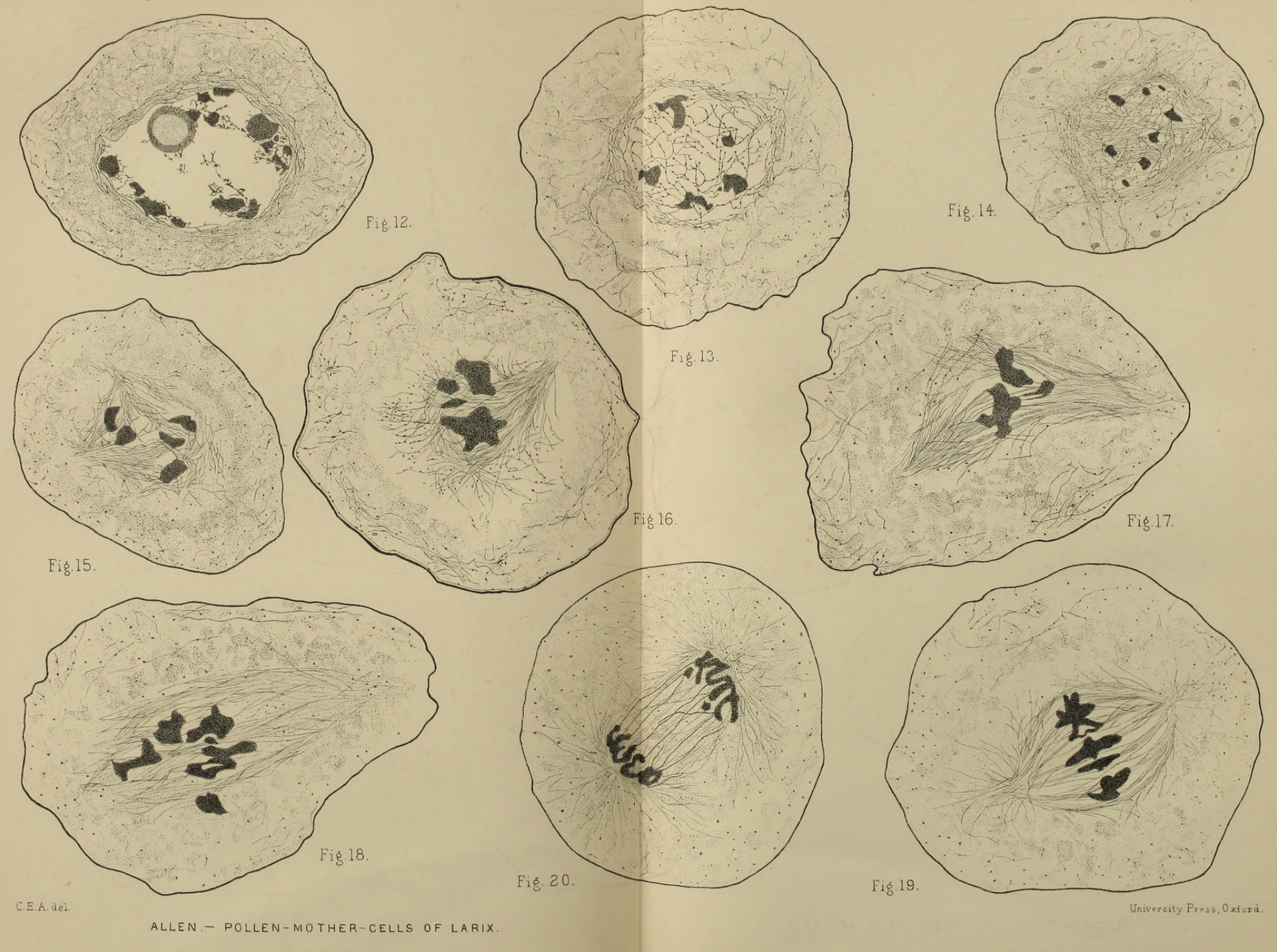




\section{$2 \mathrm{BHL}$ Biodiversity Heritage Library}

Allen, Charles E. 1903. "The early stages of spindle-formation in the pollen-mother-cells of Larix." Annals of botany 17, 281-312. https://doi.org/10.1093/oxfordjournals.aob.a088918.

View This Item Online: https://www.biodiversitylibrary.org/item/235015

DOI: https://doi.org/10.1093/oxfordjournals.aob.a088918

Permalink: https://www.biodiversitylibrary.org/partpdf/318716

\section{Holding Institution}

Smithsonian Libraries

\section{Sponsored by}

Biodiversity Heritage Library

\section{Copyright \& Reuse}

Copyright Status: Not in copyright. The BHL knows of no copyright restrictions on this item.

This document was created from content at the Biodiversity Heritage Library, the world's largest open access digital library for biodiversity literature and archives. Visit BHL at https://www.biodiversitylibrary.org. 